Bangladesh J. Bot. 42(1): 123-130, 2013 (June)

\title{
COMPARATIVE ANATOMY OF STEM AND LEAF OF RICOTIA L. GROWING IN TURKEY
}

\author{
Selami Selvi ${ }^{*}$ and Mehmet Yavuz PaKsoy ${ }^{1}$ \\ Balıkesir University, Altınoluk Vocational School, Programme of Medicinal and Aromatic Plants, \\ 10870 Edremit-Balıkesir, Turkey
}

Key words: Ricotia, Cruciferae, Anatomy, Stem, Leaf

\begin{abstract}
The present paper deals with a comparative anatomy of stem and leaf of Ricotia species growing in Turkey. In addition, stomatal index and rate of these species were calculated. A diagnostic key based on combined stem, leaf and leaf epidermal characteristics were presented. The presence or absence of trichome, cortex parenchyma layer, sclerenchyma, mesophyll structure and epidermal surface were found to be important characters for the identification of Ricotia species.
\end{abstract}

\section{Introduction}

Brassicaceae is one of the largest families of angiosperm comprising 338 genera and 3709 species and distributed throughout the world, mainly in temperate regions of the Northern Hemisphere (Al-Shehbaz 1984, Warwick et al. 2006, Kasem et al. 2011). The major centres of distribution of the family are in the Irano-Turanian, Mediterranean and Saharo-Sindian regions (Hedge 1976). Turkey is one of the richest countries in the world in terms of the number of species of the Brassicaceae represented by 571 species 65 subspecies, 24 varieties and approximately 660 taxa belonging to 91 genera (Al-Shehbaz et al. 2007). The genus Ricotia is represented by nine species which are distributed in the South East Europe, Eastern Mediterranean and adjacent Middle East (Burtt 1951, Appel and Shehbaz 2003). In the flora of Turkey, there are 6 species (Ricotia tenuifolia Sibth. \& Sm., R. sinuata Boiss. \& Heldr., R. carnosula Boiss. \& Heldr., $R$. davisiana B.L. Burtt., R. varians B.L. Burtt. and R. aucheri (Boiss.) B.L. Burtt). Ricotia has five endemic species in Turkey. The rate of endemism of Ricotia species in the flora of Turkey is 83.3\% (Davis 1985).

Metcalfe and Chalk (1957) studied the anatomy of the family Brassicaceae and determined the diagnostic anatomical characteristics as epidermal cell type, stoma type and the arrangement of the sclerenchymatic cells around the vascular bundles of the leaves.

The anatomical properties of Ricotia have not so far been studied. Therefore, the purpose of this study was to investigate the anatomical properties as well as to find out anatomical peculiarities of different species of Ricotia.

\section{Materials and Methods}

Plant specimens were collected from different localities in Turkey and had been submitted in Tunceli University Herbarium (Table 1). Anatomical studies were carried out on specimens preserved in $70 \%$ alcohol. Cross-sections of stem and leaves were stained with phloroglucinol$\mathrm{HCl}$ solutions (Yakar-Tan 1982) and chlorophyll in leaves was removed with chloral hydrate.

Stomatal density on abaxial and adaxial surfaces of the leaf was counted under a light microscope. Stomatal index was calculated according to the method of Meidner and Mansfield (1968). Stomatal terminology and the leaf epidermal terminology were based on the classification

\footnotetext{
*Author for correspondence: <sselvi2000@yahoo.com>. ${ }^{1}$ Tunceli University, Faculty of Engineering,
} Department of Enviromental Engineering, Tunceli, Turkey. 
proposed by Dilcher (1974) and Wilkinson (1979), respectively. Measurements and photographs were taken using Olympus BX 51 and Nikon Eclipse E600 binocular light microscopes.

Table 1. Specimens used for anatomical studies and localities of specimen collection.

\begin{tabular}{ll}
\hline Species & Habitat, altitute, date of collection and collector's number \\
\hline R. tenuifolia & Antalya; between Finike and Elmal, Calcareus rocky, $390 \mathrm{~m}, 24.04 .2010$, Paksoy 1080 \\
R. sinuata & Antalya; Kemer, Tahtalı mount, Cableway station, roadsides, 100 m, 24.04.2010, Paksoy \\
& 1078 \\
R. carnosula & Antalya; Kemer, Göynük canyon, around Göynük creek, calcareus slopes, $10 \mathrm{~m}$, \\
& 24.04.2010, Paksoy 1075 \\
R. davisiana & Antalya; Kemer, Tahtalı mount, Peynirlik location, $1600 \mathrm{~m}, 17.07 .2010$, Paksoy 1098 \\
R. varians & Isparta; Aksu, Dedegöl mount, Obruk plateau, 1350 m, 01.08.2010, Paksoy 1104 \\
R. aucheri & Kahramanmaraş; Çağlayancerit, Öksüz mount, Akdut location, calcareous mobile slopes, \\
& 1200 m, 11.06.2011, Paksoy 1094 \\
\hline
\end{tabular}

\section{Results and Discussion}

Comparative anatomical characters of stem and leaf of Ricotia species are given in Tables 2 and 3, respectively. Table 4 shows the features of the leaf epidermis of Ricotia species.

Table 2. Stem anatomical characters of Ricotia.

\begin{tabular}{llccccc}
\hline Taxa & $\begin{array}{l}\text { Presence/absence } \\
\text { of trichomes }\end{array}$ & \multicolumn{2}{c}{ Cortex } & Pericycle & $\begin{array}{c}\text { İterfascicular } \\
\text { region }\end{array}$ & Phloem \\
\cline { 3 - 4 } & Parenchyma & Endodermis & & & \\
\hline R. tenuifolia & Absent & $3-5$ & 1 & $1-2$ & Unclearly & $2-5$ \\
R. sinuata & Present (sparsely) & $3-4$ & 1 & $1-2$ & Unclearly & $3-5$ \\
R. carnosula & Absent & $3-4$ & 1 & 1 & Unclearly & $2-5$ \\
R. davisiana & Present (densely) & $8-10$ & 1 & 1 & Clearly & $2-6$ \\
R. varians & Absent & $6-10$ & 1 & $1-2$ & Clearly & $2-6$ \\
R. aucheri & Absent & $6-10$ & 1 & $2-4$ & Clearly & $3-11$ \\
\hline
\end{tabular}

Table 3. Leaf anatomical characters of Ricotia.

\begin{tabular}{lllllcc}
\hline Taxa & Presence/absence & Mesophyll & Palisade & Spongy & \multicolumn{2}{c}{ Middle vascular bundle } \\
\cline { 5 - 6 } & of trichomes & type & layer & layer & Sclerenchyma & Bundle sheath \\
\hline R. tenuifolia & Absent & Bifacial & $1-2$ & $3-5$ & Absent & Present \\
R. sinuata & Present (sparsely) & Bifacial & $2-3$ & $2-4$ & Absent & Present \\
R. carnosula & Absent & Bifacial & $1-2$ & $3-5$ & Absent & Present \\
R. davisiana & Present (densely) & Equifacial & $1-2$ & $2-4$ & Absent & Present \\
R. varians & Absent & Equifacial & $2-4$ & $1-2$ & Absent & Present \\
R. aucheri & Absent & Equifacial & $2-4$ & $2-3$ & Present & Present \\
\hline
\end{tabular}

Stem anatomy: In a cross section, the single-layered epidermis was found with a very thin cuticle on the outside $(0.5-1.5 \mu \mathrm{m})$. The surface was covered with simple hairs $(1-4$ cells) or without hairs. Amphistomatic or epistomatic type of stomata were present on the epidermis. Cortex layer consists of parenchyma 3 - 10 layers, thin-walled, with regularly oval or round shaped cells. Cortex parenchyma also contained starch granules. Underneath cortex parenchyma, there was a single layered rectangular or oval shaped endodermis. Pericycle is underneath 
endodermis. It was usually sclerenchymatic and surrounding on vascular bundles or cup-like 1-3 layers on phloem. The number of vascular bundles arranged in a ring is $7-16$. Interfascicular region was located in between vascular bundles. Phloem was 4 - 7 layers and consisted of irregular and squashed cells. Cambium cells were not clear. Pith region occurred in the center of the stem composed of large orbicular or polygonal parenchymatic cells.
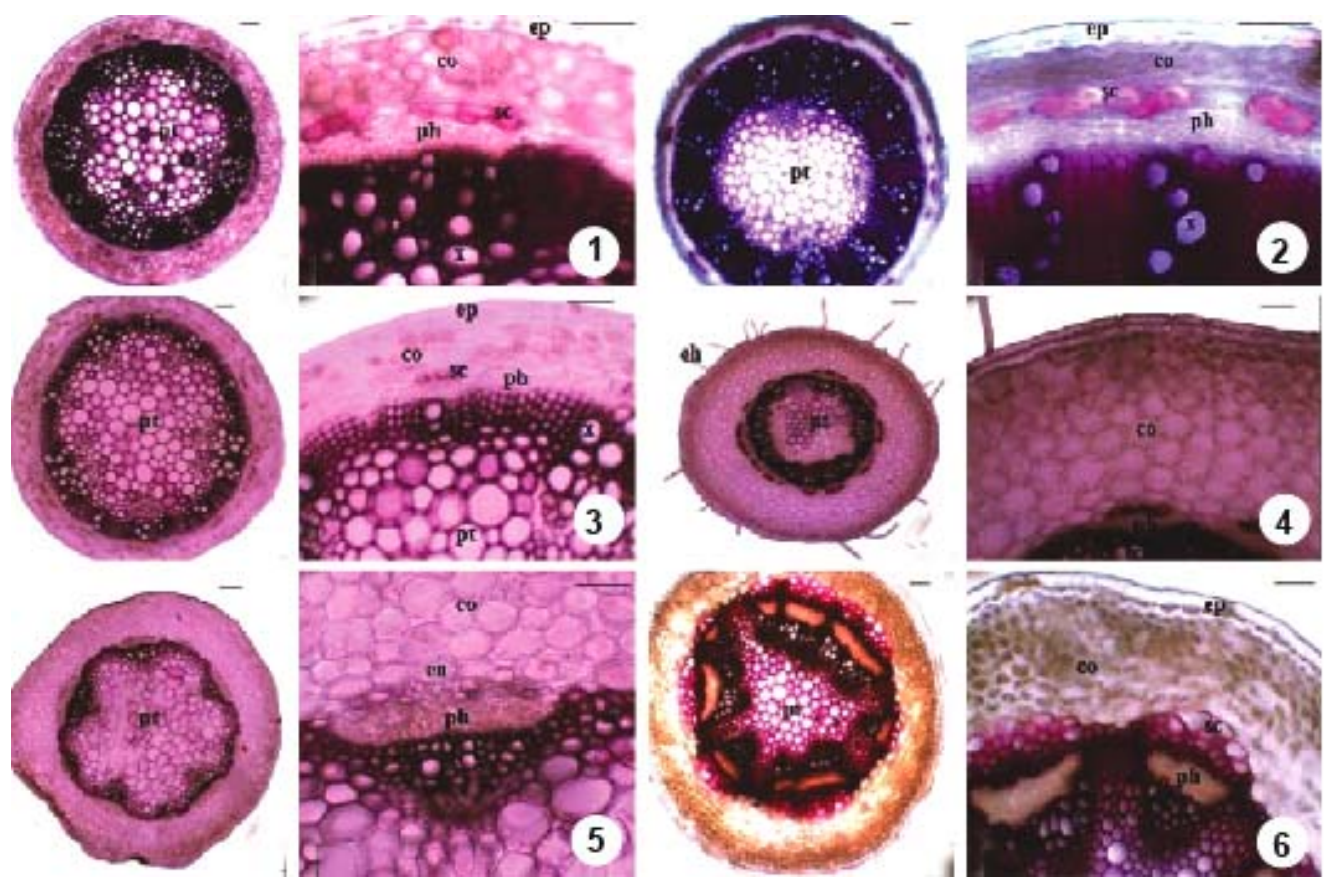

Fig. 1. Cross-section of stem of Ricotia species. 1. R. tenuifolia, 2. R. sinuata, 3. R. carnosula, 4. R. davisiana, 5. R. varians, 6. R. aucheri. cu: cuticle, ep: epidermal cell, sc: stomata cell. (Bars: $20 \mu \mathrm{m})$. co: cortex, eh: grandular hair, en: endodermis, ph: phloem, pt: pith and x: xylem.

Leaf anatomy: In the cross section of the leaf, there was a thin cuticle on the upper and lower epidermis. Both epidermal cells was isodiametric and rectangular, oval or cubic in shape. Surface of epidermis was covered with simple hairs ( $1-4$ cells) or without hairs. Stomata were present on both surfaces of the leaf (amphistomatic type). These were raised above the surface or located on the same level as epidermal cells. In surface section, 3 different types of the epidermal cell walls were found which including large waves (sinuate), mild waves (undulate) or wave (straight). Stomata type was Cruciferous type (anisocytic) or rarely Ranunculaceous (anomocytic) type. The stomatal index is $21.1-33.3$ (upper surface) and 15.8 - 31.9 (lower surface), while stomatal index ratio is between 0.6 and 1.43. Mesophyll consisted of palisade and spongy parenchyma cells. Palisade parenchyma cells were 1 - 4 layered, cylindrical whereas spongy parenchyma cells were 1 - 5 layered and round or oval in shape. Mesophyll were bifacial and equifacial. Vascular bundles were embedded in mesophyll and collateral type. They were surrounded by parenchymatic bundle sheath. Sclerenchymatic tissue on the bundles were present or absent. The xylem faces upper surface as phloem faces the lower epidermis. Sclerenchyma on phloem tissue was present or absent. 


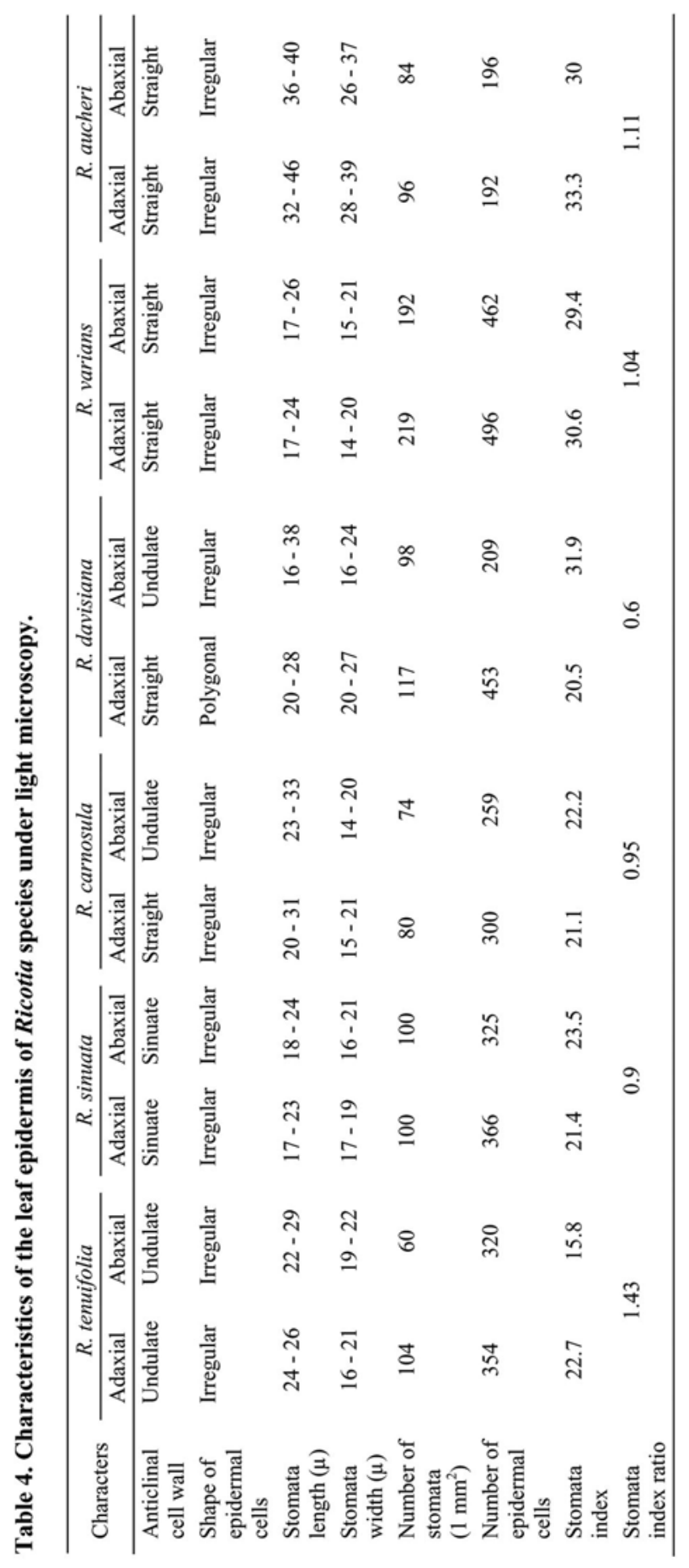


Ricotia species have been shown the typical features of the family Brassicaceae (Metcalfe and Chalk 1957). Anatomically, important characters for identification of Ricotia species were presence or absence of trichome, cortex parenchyma layer, presence or absence of sclerenchyma, mesophyll structure, and epidermal surface.

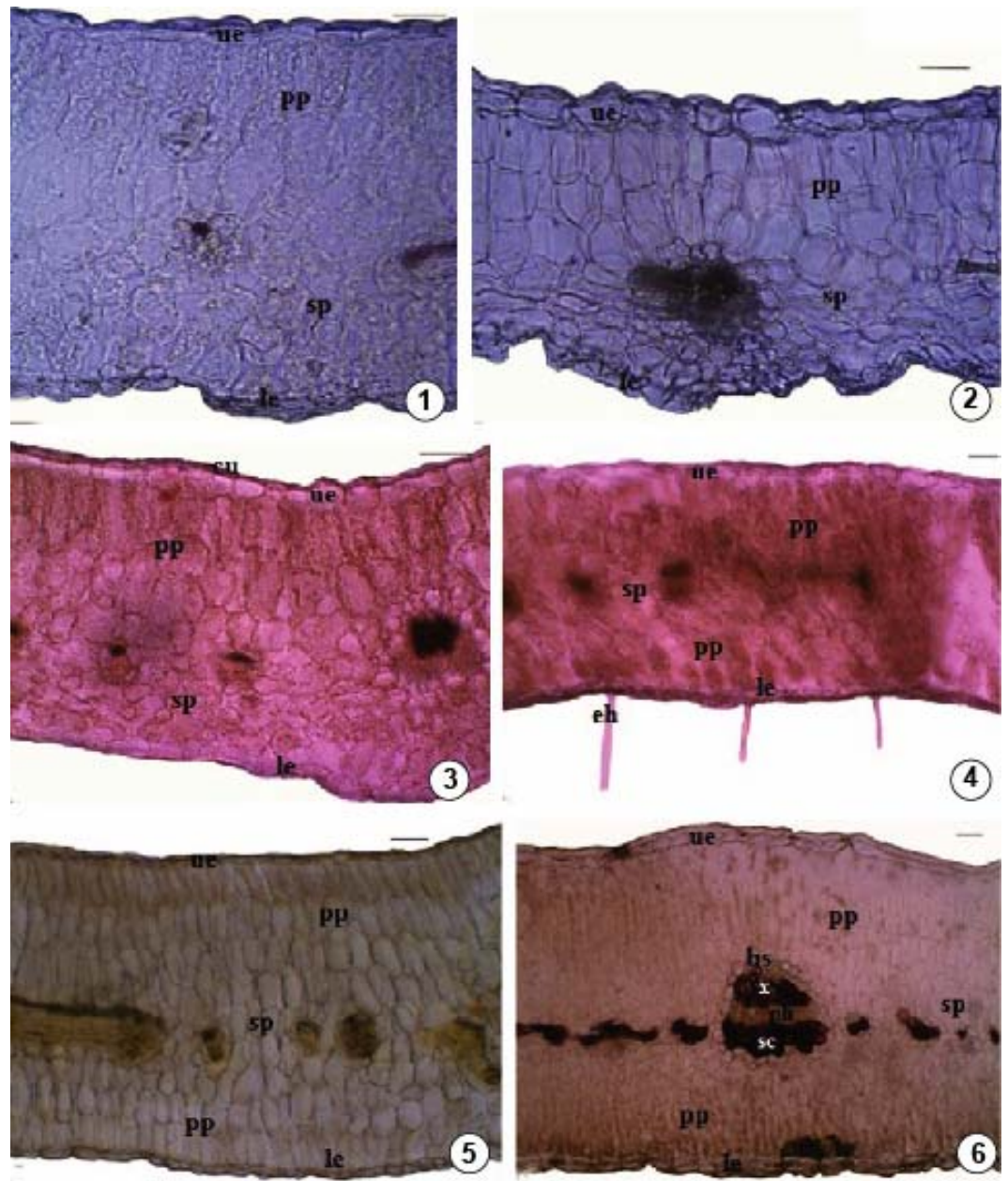

Fig. 2. Cross-section of leaves of Ricotia species. 1. R. tenuifolia, 2. R. sinuata, 3. R. carnosula, 4. $R$. davisiana, 5. R. varians, 6. R. aucheri. cu: cuticle, eh: eglandular hair, ue: upper epidermis (adaxial surface), pp: palisade parenchyma, sp: spongy parenchyma, bs: bundle sheath, x: xylem, ph: phloem, sc: sclerenchyma and le: lower epidermis (abaxial surface). (Bars: $20 \mu \mathrm{m}$ ).

The stomata of Ricotia species were surrounded by three subsidiary cells of which one was usually much smaller than the other two, the so-called Cruciferous (Anisocytic) type. Rarely stoma surrounded by a limited number of cells which were indistinguishable in size, shape, or form from those of the remainder of the epidermis, the so-called Ranunculaceous (Anomocytic) type (Fig. 5). Also, the stomatal index of these species varied from $21.1-33.3$ (upper surface) and 15.8 - 31.9 (lower surface) and the stomatal index ration varied between 0.6 and 1.43 . Three different types of the epidermal cell walls were seen. These are sinuate ( $R$. sinuata), undulate 

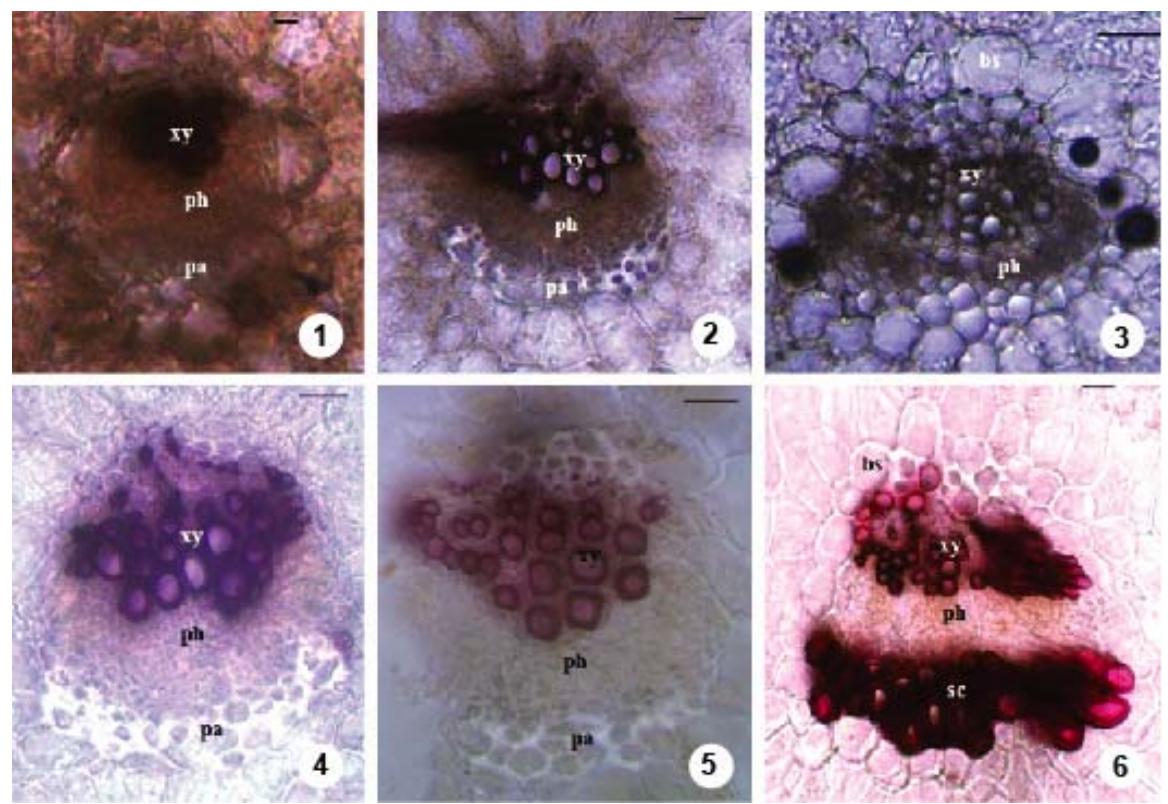

Fig. 3.Middle vascular bundles of leaves of Ricotia species. 1. R. tenuifolia, 2. R. sinuata, 3. R. carnosula, 4. $R$. davisiana, 5. R. varians, 6. R. aucheri. bs: bundle sheath, xy: xylem, ph: phloem, sc: sclerenchyma and pa: parenchyma (Bars: $20 \mu \mathrm{m})$.
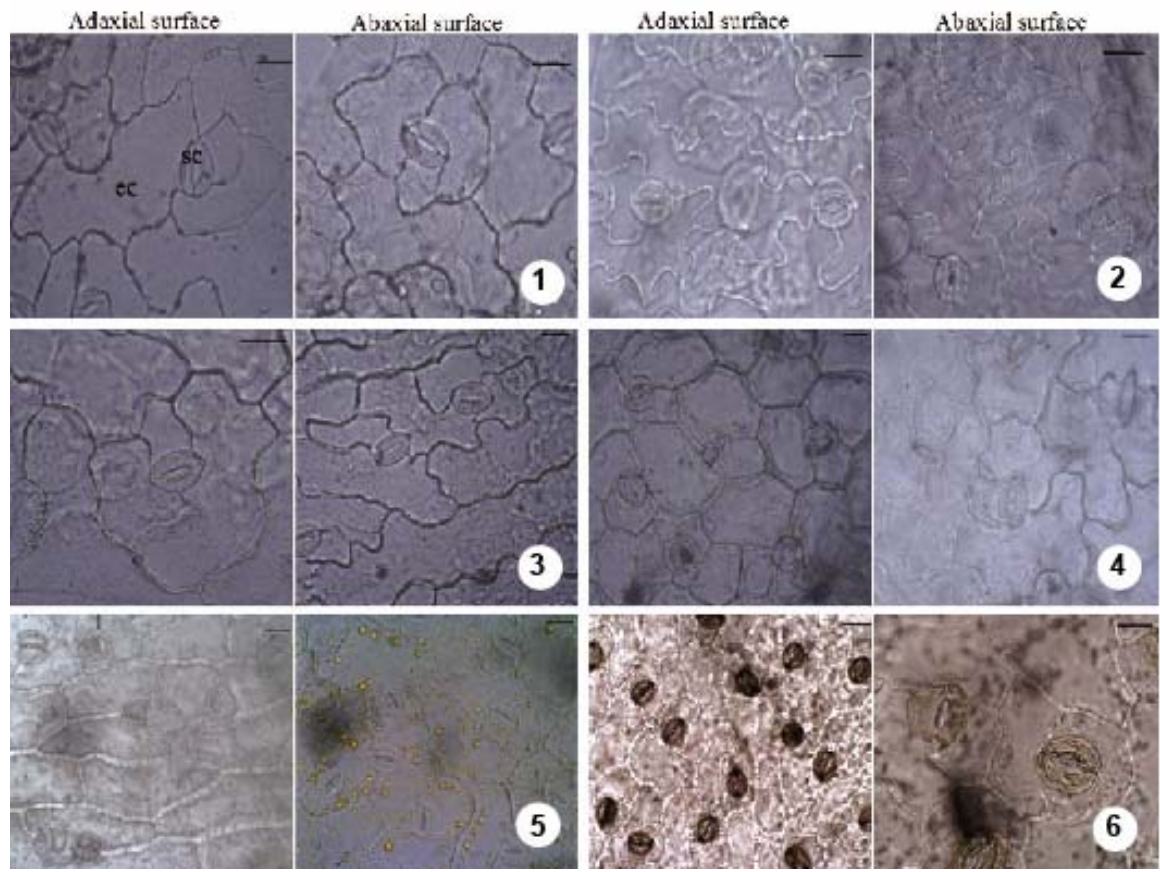

Fig. 4. Adaxial and abaxial epidermal surfaces of leaves of Ricotia species. 1. R. tenuifolia, 2. R. sinuata, 3. $R$. carnosula, 4. $R$. davisiana, 5. $R$. varians, 6. R. aucheri. cu: cuticle, ec: epidermis cell and sc: stomata cell. (Bars: $20 \mu \mathrm{M}$ ). 
(R. tenuifolia, R. carnosula and R. davisiana) and straight (R. carnosula, $R$. davisiana, $R$. varians and $R$. aucheri) (Fig. 4). The pattern of mesophyll significant anatomical character for Ricotia species. R. tenuifolia, $R$. sinuata and $R$. carnosula are bifacial (dorsiventral) while $R$. davisiana, $R$. varians and $R$. aucheri are equifacial (isobilateral) (Fig. 2). R. davisiana can be easily separated anatomically from other species. One of the most important characters of this species is the trichome (simple, 1 - 4 celled) which are found densely on stem and leaf. Another important character is the presence of sclerenchyma on vascular bundle of leaf (Figs 1, 3). Anatomical characters of $R$. tenuifolia and $R$. sinuata are quite similar to each other but, as can be seen by comparing with Fig. 3, adaxial and abaxial epidermal walls of leaves of $R$. sinuata is apparently sinuate while $R$. tenuifolia is undulate (Fig. 4).
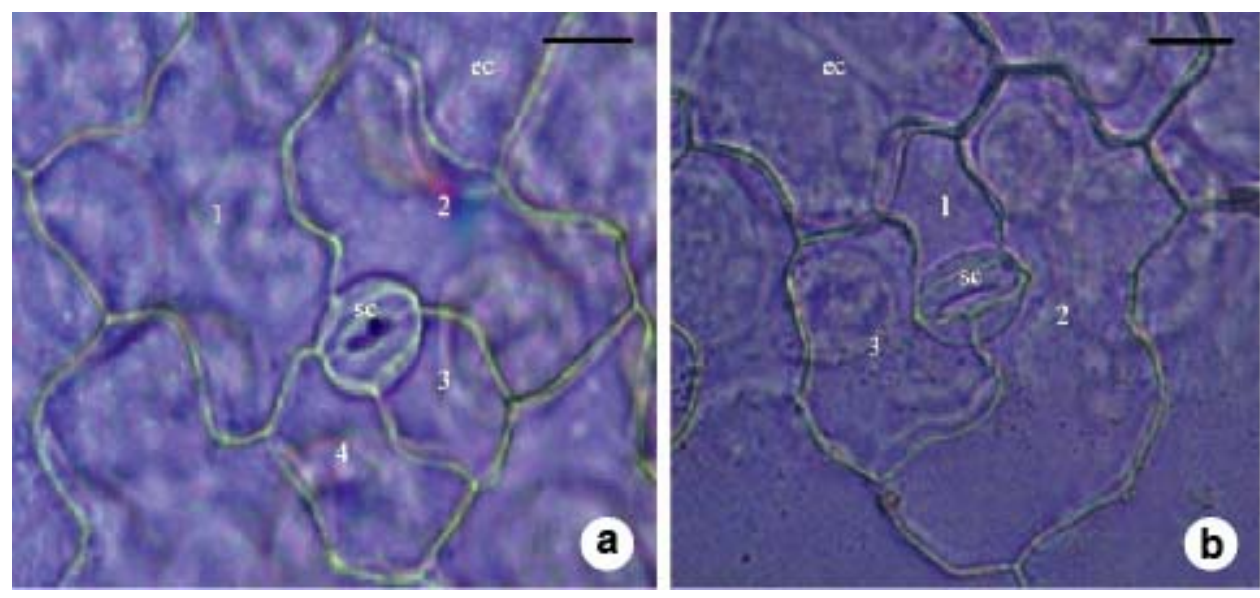

Fig. 5. Stomata types of Ricotia species. A. Anomocytic type, B. Anisocytic type. sc: stoma cell and ec: epidermis cell (Bars : $20 \mu \mathrm{m})$.

Based on the anatomical features of the leaf, leaf surface and stem, a diagnostic key is presented below.

1. Stem cortical parenchyma consists of 3 - 5 layers, interfascicular bundles are not clear; mesophyll type is bifacial; anticlinal walls of adaxial epidermal surface are straight or undulate.

2. Pith region is narrow. Vascular bundles occupy the most space in stem. Phloem rises up to 11 layers in stem.

3. Stem and leaf surface are glabrous; Epidermal surface of leaves are straight or undulate

3. Stem and leaf surface are sparsely haired (1 - 2 cells), Epidermal surface of leaves are sinuate

R. sinuata

2. Pith region is wide. Vascular bundles occupy less space in stem. Phloem rises up to maximum 6 layers in stem

R. carnosula

1. Stem cortical parenchyma is 6 - 10 layered, interfascicular bundles are present; mesophyll type is equifacial; anticlinal walls of adaxial epidermal surface are all straight. 
4. Stem and leaf surface denser, simple hair (1 - 4 cells); in leaf, sclerenchymatic tissue on the bundles is absent. Shape of epidermis cells of adaxial epidermal surface is polygonal

R. davisiana

4. Stem and leaf surface are glabrous or very sparsely haired. In leaf sclerenchymatic tissue on the bundles is present or absent. Shape of epidermal cells of adaxial epidermal surface polygonal

5. Sclerenchyma on middle vascular bundle in leaf is absent. Pericycle is one layered and vascular bundles are not surrounded by pericycle

5. Sclerenchyma on middle vascular bundle in leaf is present. Pericycle is many layered and vascular bundles are surrounded by pericycle.

R. aucheri

\section{References}

Al-Shehbaz IA 1984. The tribes of Cruciferae (Brassicaceae) in the southeastern United States. J. Arn. Arb. 65: 343-373.

Al-Shehbaz IA, Mutlu B and Dönmez AA 2007. The Brassicaceae (Cruciferae) of Turkey, updated. Turk. J. Bot. 31: 327-336.

Appel O and Al-Shehbaz IA 2003. Cruciferae. In: The families and genera of vascular plants, Kubitzki K (Ed), pp. 75-174. Springer, Berlin.

Burtt BL 1951. The Genus Ricotia. Kew Bulletin. 6(1):123-132.

Davis PH 1985. Alyssum L. In: Flora of Turkey and the East Aegean Islands. Vol. 1, Davis PH (Ed), pp. 353355. Edinburgh Univ. Press, North America.

Dilcher D 1974. Approaches to the identification of angiosperm leaf remains. The Bot. Rev. 40(1): 3-157.

Hedge IC 1976. A systematic and geographical survey of old World Cruciferae. In: The biology and chemistry of the Cruciferae, Vaughan JG, Macleod AJ and Jones BMG (Eds), pp. 1-46. London.

Kasem WT, Ghareeb A and Marwa E 2011. Seed morphology and seed coat sculpturing of 32 taxa of family Brassicaceae. J. Am. Stud. 2: 166-178.

Meidner H and Mansfield TA 1968. Physiology of stomata. McGraw-Hill, New York, U.S.A. 179 pp.

Metcalfe CR and Chalk L 1957. Anatomy of The Dicotyledons (Leaves, stem and wood in relation to taxonomy with notes on economic uses), Vol. 1, pp. 79-87. Oxford University Press, Amen House, London.

Warwick SI, Francis A and Al-Shehbaz IA 2006. Brassicaceae: Species checklist and database on CDRom. Pl. Syst. Evol. 259: 249-258.

Wilkinson HP 1979. The plant surface (mainly leaf). In: Anatomy of the dicotyledons, Metcalfe CR and Chalk L (Eds), Vol. 1, pp. 97-165. Clarendon Press, Oxford, UK.

Yakar-Tan N 1982. Bitki Mikroskopisi Klavuz Kitabı. İstanbul University, Faculty of Science Publishing, pp. 166. İstanbul, Turkey.

(Manuscript received on 4 August, 2012; revised on 8 December, 2012) 